\title{
Sensitivity of Northern Highbush Blueberry Cultivars to Soil Water Deficits during Various Stages of Fruit Development
}

\author{
Khalid F. Almutairi \\ Department of Horticulture, Agricultural and Life Sciences Building 4017, \\ Oregon State University, Corvallis, OR 97331
}

\section{David R. Bryla}

U.S. Department of Agriculture, Agricultural Research Service, Horticultural Crops Research Unit, 3420 NW Orchard Avenue, Corvallis, OR 97330

\author{
Bernadine C. Strik \\ Department of Horticulture, Agricultural and Life Sciences Building 4017, \\ Oregon State University, Corvallis, OR 97331
}

Additional index words. drought, fruit quality, irrigation, Vaccinium corymbosum, yield

\begin{abstract}
In many regions, water limitations are increasing because of frequent and persistent droughts and competition for water resources. As a result, growers in these regions, including those producing blueberries, must limit irrigation during drier years. To identify the most critical periods for irrigation, we evaluated the effects of soil water deficits during various stages of fruit development on different cultivars of northern highbush blueberry (Vaccinium corymbosum $L$.). The study was conducted for 2 years in western Oregon and included two early season cultivars, 'Earliblue' and 'Duke', a midseason cultivar, 'Bluecrop', and two late-season cultivars, 'Elliott' and 'Aurora'. Volumetric soil water content and stem water potentials declined within 1 to 2 weeks with no rain or irrigation in each cultivar and were lowest during the later stages of fruit development. Water deficits reduced berry weight by $10 \%$ to $15 \%$ in 'Earliblue' and 'Elliott' when irrigation was withheld in the second year during early or late stages of fruit development and by $6 \%$ to $9 \%$ in 'Aurora' when irrigation was withheld in either year during the final stages of fruit development. However, water deficits only reduced yield significantly in 'Aurora', which produced 0.8 to $0.9 \mathrm{~kg} /$ plant fewer fruit per year when irrigation was withheld during fruit coloring. In many cases, water deficits also reduced fruit firmness and increased the concentration of soluble solids in the berries, but they had inconsistent effects on titratable acidity and sugar-to-acid ratios. As a rule, water deficits were most detrimental during later stages of fruit development, particularly in midseason and late-season cultivars, which ripened in July and August during the warmest and driest months of the year.
\end{abstract}

Received for publication 1 Oct. 2020. Accepted for publication 11 Nov. 2020.

Published online 23 December 2020.

We thank King Saud University for providing financial support to K.F.A., the U.S. Department of Agriculture for funding the research (CRIS number 2072-21000-048-00D), and L. DeVetter and P. Schreiner for reviewing the manuscript.

Mention of trade names or commercial products in this publication is solely for the purpose of providing specific information and does not imply recommendation or endorsement by the U.S. Department of Agriculture.

K.F.A. is a former $\mathrm{PhD}$ student. Current address: College of Food and Agricultural Sciences, King Saud University, Riyadh, Saudi Arabia.

D.R.B. is the corresponding author. E-mail: david. bryla@usda.gov.

This is an open access article distributed under the CC BY-NC-ND license (https://creativecommons. org/licenses/by-nc-nd/4.0/).
Northern highbush blueberry is a shallowrooted plant that can easily deplete available soil water within a few days without rain or irrigation (Bryla and Strik, 2007; Bryla et al., 2011; Ehret et al., 2012, 2015). Consequently, most commercial fields of blueberry are irrigated on a regular basis by drip or sprinklers (Holzapfel, 2009). In the northwestern United States, summers are warm and dry, and growers usually apply 25 to $50 \mathrm{~mm}$ of water per week throughout the growing season (Bryla, 2011). However, water limitations are increasing in the region due to frequent episodes of drought and greater demands for water by other sectors (Dalton et al., 2013). Therefore, many growers must limit the amount of water used for irrigation in drier years. Water limitations occurring during fruit development tend to have the most dramatic effect on fruit production of blueberry, readily affecting both yield and fruit quality by reducing the size and weight of the berries (Bryla et al., 2009; Mingeau et al., 2001; Wilk et al., 2009).

Like many fruits, blueberries have a double-sigmoid pattern of development (Eck, 1986; Godoy et al., 2008; Shimura et al., 1986). The first stage of development, or stage I, occurs after fruit set, when berry size and total dry weight increase through rapid cell division. In stage II, there is little change in berry size or biomass as the embryos are developing. In stage III, the berries increase in size through cell enlargement via water uptake. Stages I and III are generally considered the periods most sensitive to water deficits during fruit development (Caspari et al., 1994; Li et al., 1989; Lotter et al., 1985; Mills and Behboudian, 1996; Ojeda et al., 2001). However, Abbott and Gough (1987) observed that it is precisely during stage II, or the middle lag phase period, of fruit development that vegetative growth is at its maximum peak for northern highbush blueberry. Vegetative growth tends to be more sensitive to water limitations than fruit growth; therefore, it is more often affected by mild or moderate water deficits than yield or fruit quality (Egea et al., 2013; Lobos et al., 2018; Romero et al., 2006).

Previously, we found that water limitations during early stages of fruit development increased fruit bud set of 'Elliott' northern highbush blueberry but had little to no effect on yield or fruit quality, whereas water limitations during later stages of development reduced yield, berry size, and fruit bud set (Almutairi et al., 2017). The objective of the present study was to build on these findings and examine the effects of soil water deficits during various stages of fruit development on different cultivars of northern highbush blueberry. The study included the following: two early season cultivars, Earliblue and Duke, which in most years ripen from mid-June to early July in western Oregon; a midseason cultivar, Bluecrop, which usually ripens from early to late July; and two late-season cultivars, Elliott and Aurora, which usually ripen from late July to late August (Strik et al., 2014). Each cultivar was exposed to water deficits at stage I, II, or III to identify the most critical periods for irrigation and to determine whether there was any potential for reducing water use at other times without any loss of production or quality.

\section{Materials and Methods}

Study site. The study was conducted for 2 years (2013-14) in an established field of northern highbush blueberry located at the Oregon State University Lewis-Brown Horticultural Research Farm in Corvallis, OR (lat. $44^{\circ} 33^{\prime} 11^{\prime \prime} \mathrm{N}$, long. $123^{\circ} 12^{\prime} 55^{\prime \prime} \mathrm{W}, 68 \mathrm{~m}$ elevation). The field was planted in Oct. 2008 with six cultivars (in order of ripening), Earliblue, Duke, Bluecrop, Draper, Elliott, and Aurora (see Vargas et al., 2015 for complete details regarding soil conditions 


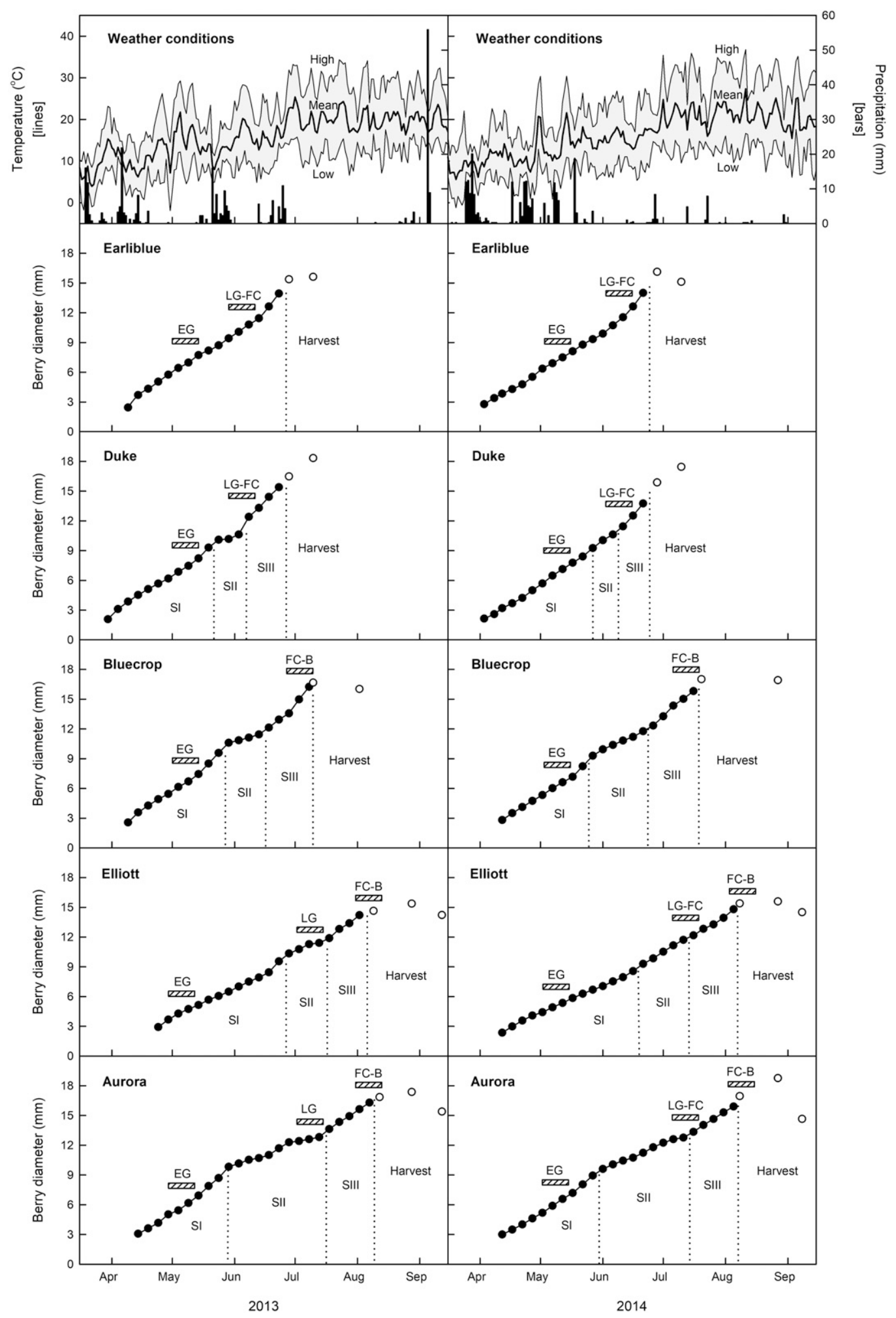

Fig. 1. Weather conditions (mean, maximum, and minimum daily temperatures and precipitation) and berry development of fully irrigated controls of earlyseason ('Earliblue' and 'Duke'), midseason ('Bluecrop'), and late-season ('Elliott' and 'Aurora') cultivars of northern highbush blueberry in 2013 and 2014. Diameters were measured nondestructively before harvest using the same berries over time $(\bullet$; stages I-III) and using random samples of picked berries on each harvest date $(\bigcirc)$. Each symbol represents the mean of five replicates. The sEm ranged from 0.01 to $0.05 \mathrm{~mm}$ and was less than the diameter of the symbols of each cultivar. Hashed bars indicate the dates when irrigation was withheld for 2 weeks from the water deficit treatments during the early green (EG), lategreen or late-green to fruit coloring (LG/LG-FC), or fruit coloring to blue (FC-B) stages of fruit development.

and site preparation). Briefly, the soil was a Malabon silty clay loam (fine, mixed, superactive, mesic Pachic Ultic Argixerolls) acidified to $\mathrm{pH} 5.5$ with elemental sulfur before planting. Each cultivar was transplanted $0.76 \mathrm{~m}$ apart on raised beds (height $0.4 \mathrm{~m} \times$ width $0.9 \mathrm{~m}$ ). The beds were centered $3.0 \mathrm{~m}$ apart and mulched every other year with an $\approx 5$-cm-deep layer of douglas fir [Pseudotsuga menziesii (Mirb.) Franco] sawdust. Preemergent herbicides were applied annually to the beds before leaf emergence, and grass 
Early season cultivars

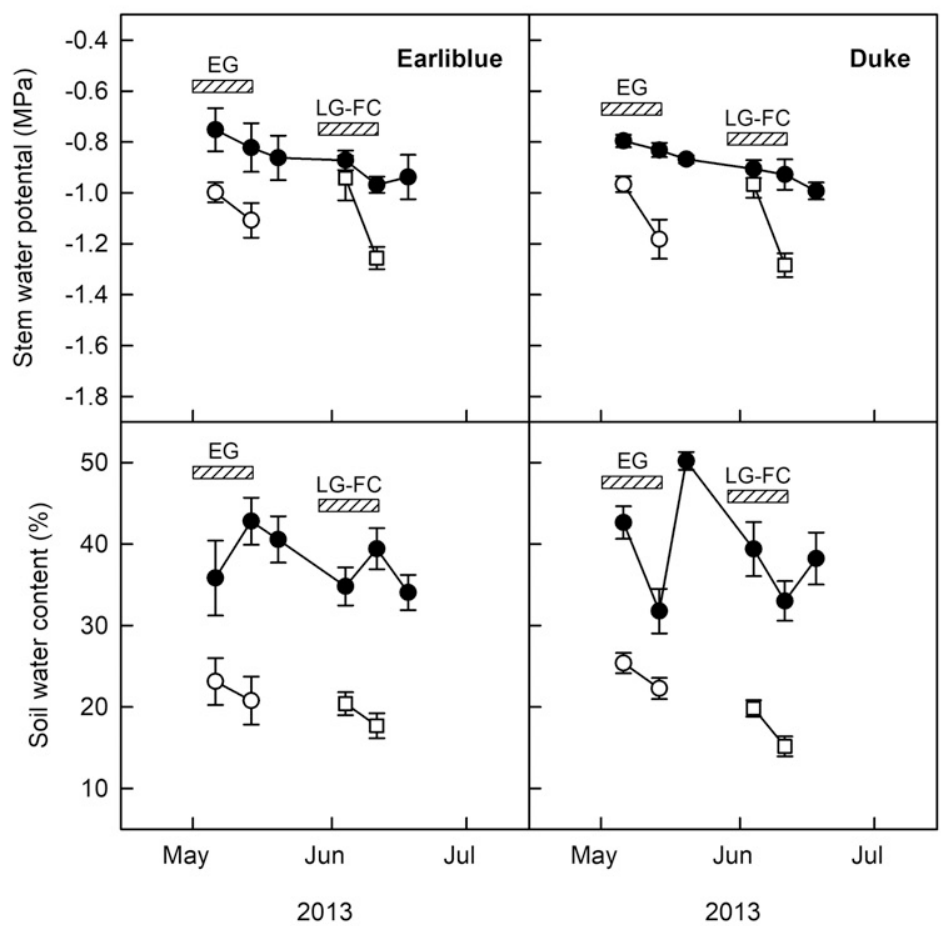

Mid-season cultivar

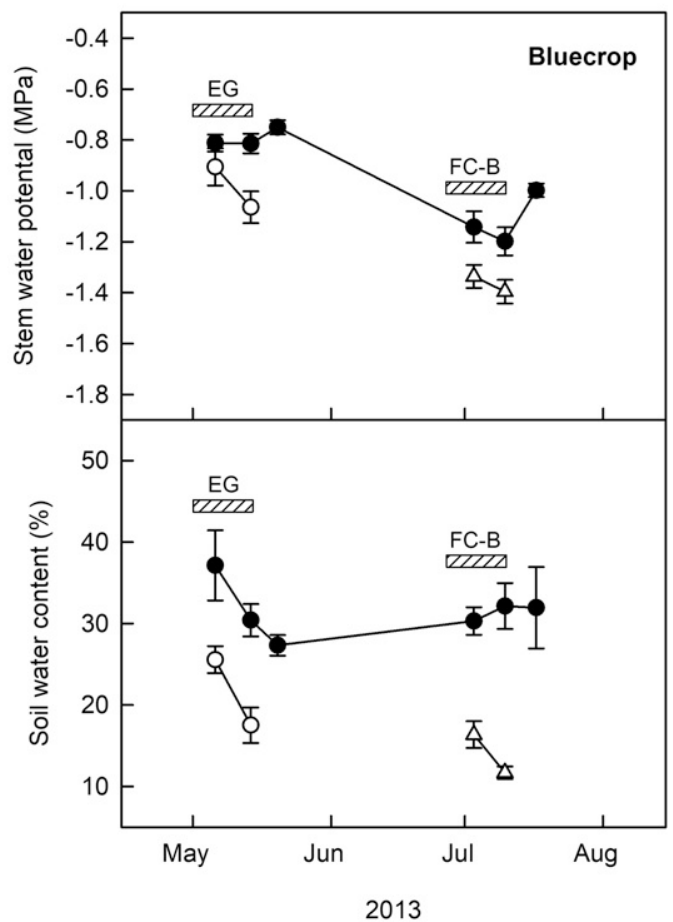

Late-season cultivars

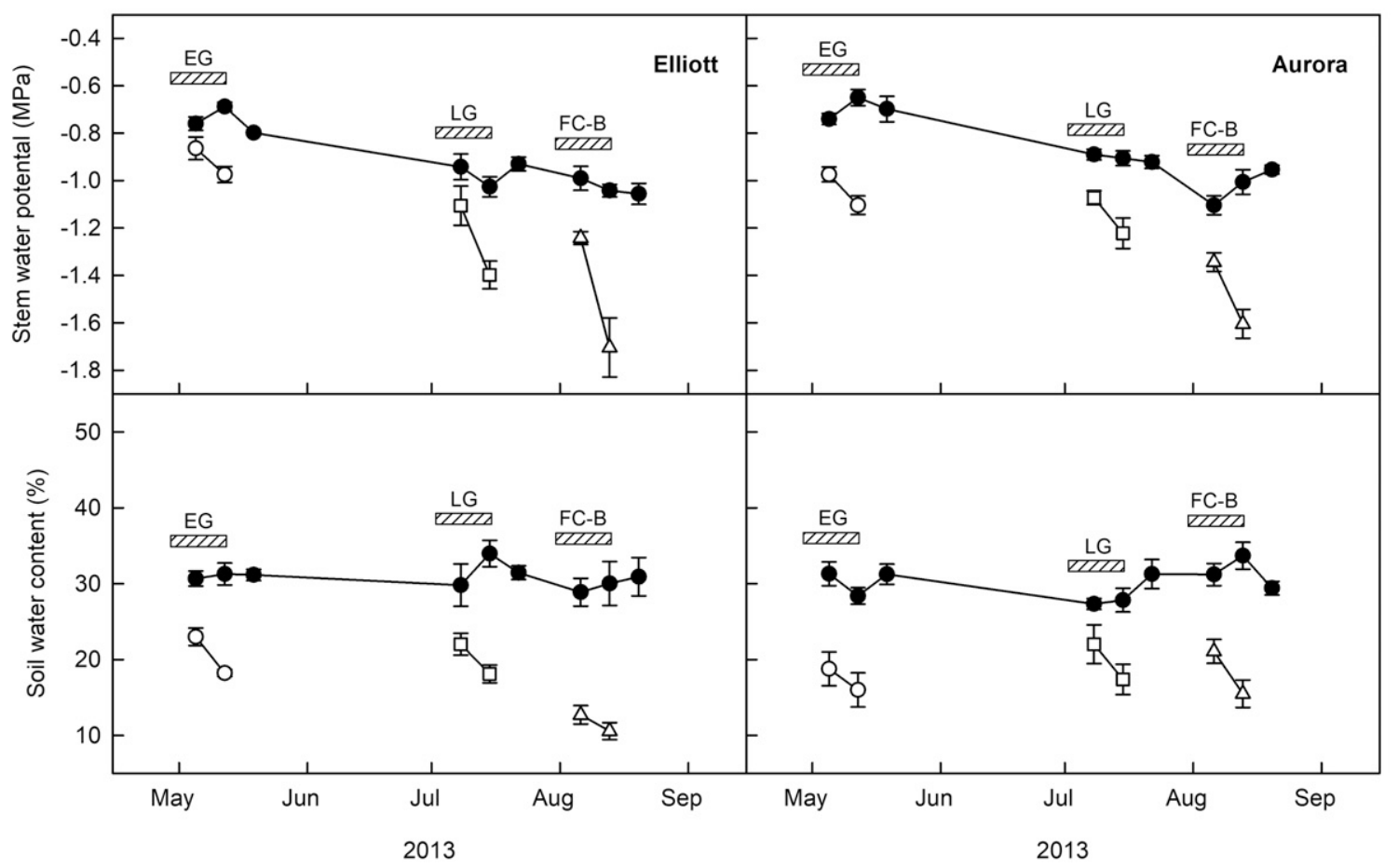

Fig. 2. Changes in mid-day stem water potential and volumetric soil water content with full irrigation ( $\bigcirc)$ or soil water deficits $(\bigcirc$, $\square$, $\triangle$ ) of early-season ('Earliblue' and 'Duke'), midseason ('Bluecrop'), and late-season ('Elliott' and 'Aurora') cultivars of northern highbush blueberry during 2013. Water deficit treatments (represented by hashed bars) were applied by withholding irrigation for 2 weeks during the early green (EG; $\bigcirc$ ), late-green or late-green to fruit coloring (LG/LG-FC; $\square$ ), or fruit coloring to blue (FC-B; $\triangle$ ) stages of fruit development (see Fig. 1 for details). Each symbol represents the mean of five replicates. Error bars represent $\pm 1 \mathrm{SE}$. Means were significantly different between treatments with full irrigation and water deficits on each date $(P<0.05)$.

alleyways were planted and mowed between the beds. Honeybee (Apis mellifera L.) hives were located directly adjacent to the field year-round. No pesticides or fungicides were applied during the study.
The planting was irrigated from April or May through September each year using two lines of drip tubing (UniRam; Netafim USA, Fresno, CA) per row. The tubing, which had integrated, $2.0 \mathrm{~L} \cdot \mathrm{h}^{-1}$, pressure-compensating drip emitters every $0.45 \mathrm{~m}$, was placed $\approx 0.2 \mathrm{~m}$ from the base of the plants and covered by the sawdust mulch. Irrigation was controlled independently for each cultivar using a timer and solenoid valves and 
Early season cultivars

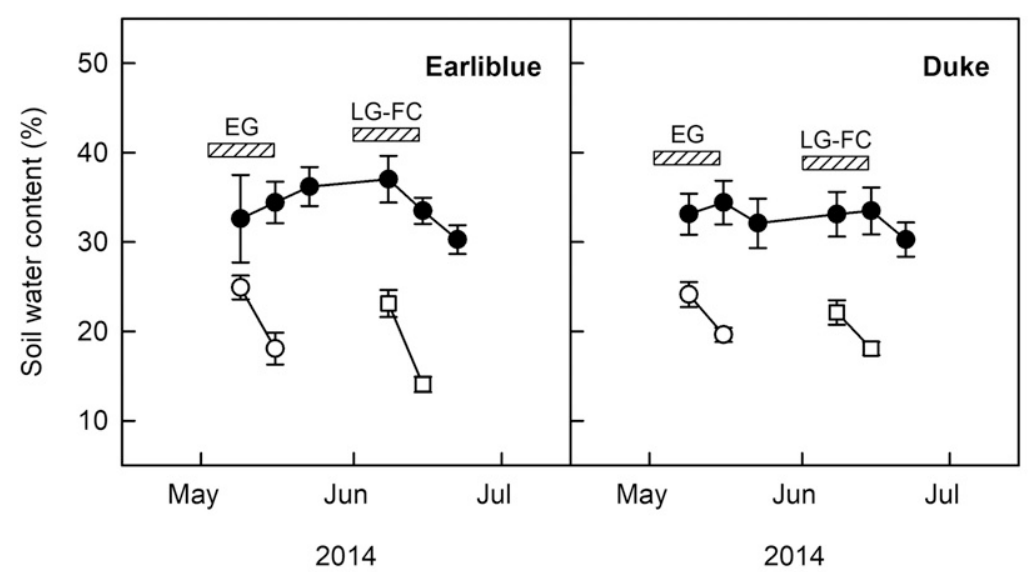

Mid-season cultivar

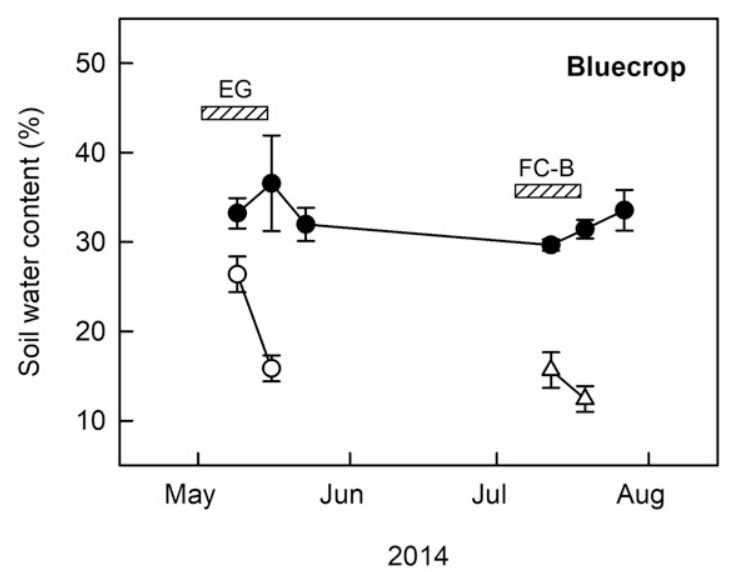

\section{Late-season cultivars}

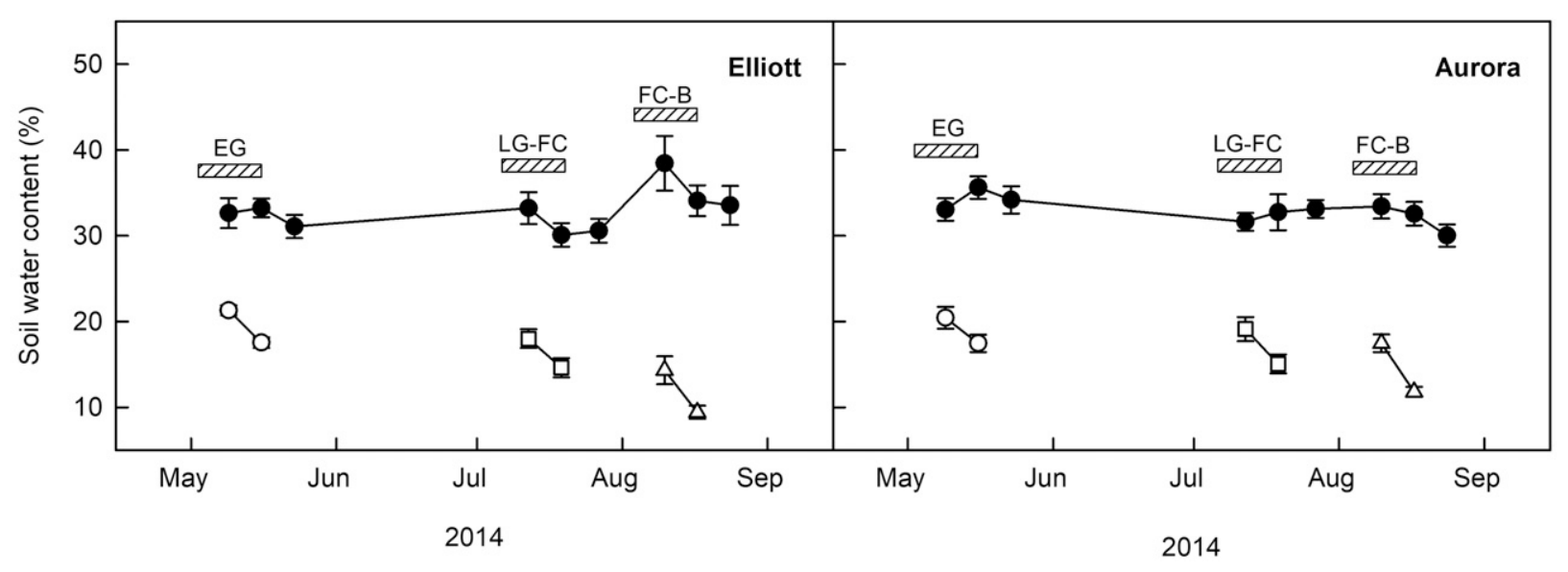

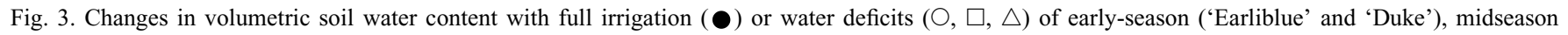
('Bluecrop'), and late-season ('Elliott' and 'Aurora') cultivars of northern highbush blueberry during 2014. Water deficits (represented by hashed bars) were applied by withholding irrigation for 2 weeks during the early green (EG; $\mathrm{O}$ ), late-green to fruit coloring (LG-FC; $\square$ ), or fruit coloring to blue (FC-B; $\triangle$ ) stages of fruit development (see Fig. 1 for details). Each symbol represents the mean of five replicates. Error bars represent \pm 1 SE. Means were significantly different between treatments with full irrigation and water deficits on each date $(P<0.05)$.

scheduled three to seven times per week based on precipitation and daily estimates of crop evapotranspiration $\left(\mathrm{ET}_{\mathrm{c}}\right)$ obtained from a nearby AgriMet weather station (http://usbr.gov/pn/agrimet) (Bryla, 2011). Each irrigation event was monitored using water meters (SRII; Sensus, Raleigh, NC) installed at the inflow for each cultivar.

The plants were fertigated with liquid urea $(20 \mathrm{~N}-0 \mathrm{P}-0 \mathrm{~K})$ once every 2 weeks, from mid-April through the end of July each year, at rates recommended by Bryla and Strik (2015). The fertilizer was applied through the irrigation system using a fertilizer injector (Mix-Rite TF10-002; DEMA, St. Louis, MO) and $\approx 5 \mathrm{~mm}$ of water on each date. Any water used for fertigation was subtracted from the irrigation requirements. No other fertilizers were applied during the study.

Experimental design. The experiment had a split-plot design, with the cultivars as main plots and four soil water deficit treatments as subplots. Each main plot consisted of two rows of eight plants and was replicated in five blocks. Subplots were randomly assigned to four consecutive plants in each main plot, and all data were collected from the middle two plants in the subplots. Plants from most of the cultivars were healthy; however, 'Draper' plants were severely stunted by phytophthora root rot (Vargas et al., 2015); therefore, they were not included in the present study. Soil water deficits were applied for 2 weeks during different stages of fruit development by withholding irrigation from the plants. Ball valves were installed on the drip lines in each treatment plot and used to stop irrigation during soil water deficits. The exact stage at which water deficits were applied varied depending on precipitation but ranged from the early green to the blue stages of fruit development of each cultivar (Fig. 1). Other than the 2week water deficit period, each treatment plot was irrigated to replace $100 \%$ of estimated $\mathrm{ET}_{\mathrm{c}}$ and compared with a control treatment plot with plants that were fully irrigated throughout the growing season. Each deficit treatment was applied to the same subplots in 2013 and 2014.
Measurements. The plants began flowering in mid to late April each year and completed fruit set in May. Berry development was measured from $\approx 75 \%$ fruit set and continued until the beginning of fruit harvest. Approximately 1 to 2 weeks before fruit set was complete, the third flower cluster from the distal end was tagged on one representative lateral per plant in each replicate. A random sample of five berries in each cluster was then marked with a small dot using a black dry marker and measured to determine the diameter every 3 to $5 \mathrm{~d}$ using digital images. The images were captured from a fixed position using a camera (Coolpix L105; Nikon Inc., Melville, NY) and analyzed using open-source software (ImageJ; http://imagej.nih.gov/ij/). A metric ruler was placed next to the cluster in each image to serve as a scale for the diameter measurements.

Soil water content was measured weekly during water deficits using a time domain reflectometry (TDR) system (Trase System; Soil Moisture Equipment Corp., Santa Barbara, CA). Stainless-steel TDR rods were inserted 
Table 1. Effects of soil water deficits at different stages of fruit development on yield and berry weight of early-season ('Earliblue' and 'Duke'), midseason ('Bluecrop'), and late-season ('Elliott' and 'Aurora') cultivars of northern highbush blueberry.

\begin{tabular}{|c|c|c|c|c|}
\hline \multirow[b]{2}{*}{ Cultivar/stage ${ }^{\mathrm{z}}$} & \multicolumn{2}{|c|}{$\begin{array}{c}\text { Yield } \\
\text { (kg/plant) }\end{array}$} & \multicolumn{2}{|c|}{$\begin{array}{l}\text { Berry } \\
\text { wt }(g)\end{array}$} \\
\hline & 2013 & 2014 & 2013 & 2014 \\
\hline \multicolumn{5}{|l|}{ Earliblue } \\
\hline Control & 3.26 & 3.41 & 1.76 & $1.89 \mathrm{a}$ \\
\hline EG & 3.27 & 3.46 & 1.48 & $1.61 \mathrm{c}$ \\
\hline LG-FC & 3.35 & 3.50 & 1.71 & $1.70 \mathrm{~b}$ \\
\hline Significance & 0.9675 & 0.8473 & 0.0688 & $<0.0001$ \\
\hline \multicolumn{5}{|l|}{ Duke } \\
\hline Control & 5.07 & 5.31 & 1.66 & 1.69 \\
\hline EG & 5.02 & 4.95 & 1.59 & 1.65 \\
\hline LG-FC & 4.35 & 4.51 & 1.74 & 1.69 \\
\hline Significance & 0.6370 & 0.5538 & 0.2721 & 0.6874 \\
\hline \multicolumn{5}{|l|}{ Bluecrop } \\
\hline Control & 6.32 & 6.49 & 1.72 & 1.74 \\
\hline EG & 5.88 & 6.15 & 1.75 & 1.82 \\
\hline FC-B & 5.20 & 5.74 & 1.85 & 1.86 \\
\hline Significance & 0.1277 & 0.2222 & 0.2477 & 0.0526 \\
\hline \multicolumn{5}{|l|}{ Elliott } \\
\hline Control & 6.15 & 6.61 & 1.62 & $1.76 \mathrm{a}$ \\
\hline EG & 5.88 & 5.99 & 1.56 & $1.53 \mathrm{~b}$ \\
\hline LG or LG-FC & 5.71 & 6.12 & 1.50 & $1.77 \mathrm{a}$ \\
\hline FC-B & 5.39 & 5.80 & 1.56 & $1.52 \mathrm{~b}$ \\
\hline Significance & 0.6246 & 0.3774 & 0.1385 & $<0.0001$ \\
\hline \multicolumn{5}{|l|}{ Aurora } \\
\hline Control & $6.05 \mathrm{a}^{\mathrm{y}}$ & $6.29 \mathrm{a}$ & $2.06 \mathrm{a}$ & $2.03 \mathrm{~b}$ \\
\hline EG & $6.03 \mathrm{a}$ & $6.32 \mathrm{a}$ & $2.03 \mathrm{ab}$ & $1.98 \mathrm{~b}$ \\
\hline LG or LG-FC & $5.82 \mathrm{a}$ & $5.98 \mathrm{a}$ & $2.09 \mathrm{a}$ & $2.10 \mathrm{a}$ \\
\hline FC-B & $5.14 \mathrm{~b}$ & $5.52 \mathrm{~b}$ & $1.93 \mathrm{~b}$ & $1.85 \mathrm{c}$ \\
\hline Significance & 0.0256 & 0.0010 & 0.0337 & $<0.0001$ \\
\hline
\end{tabular}

${ }^{\mathrm{z}}$ Water deficits were applied by withholding irrigation for 2 weeks during the early green (EG), late-green or late-green to fruit coloring (LG/LG-FC), or fruit coloring to blue (FC-B) stages of fruit development (see Fig. 1 for details). ${ }^{\mathrm{y}}$ Means $(\mathrm{n}=5)$ were separated within each cultivar and year by Fisher's protected least significant difference test $(P \leq 0.05)$.

vertically under a drip emitter located near the center of each plot to a depth of $30 \mathrm{~cm}$. Stem water potential was also measured weekly during water deficits in 2013. These measurements were performed during mid-day (1330-1530 HR) using a pressure chamber (Model 600; PMS Instrument Co., Albany, OR), following the recommendations of Hsiao (1990). For each measurement, two or three fully expanded leaves on the tip of a stem were enclosed for at least $1 \mathrm{~h}$ in plastic bags laminated with aluminum foil to equilibrate the water potentials of the leaves with the stem (McCutchan and Shackel, 1992). This procedure reduces variability in the water potential measurements of woody perennials such as blueberry.

Ripe fruit were picked by hand on two or three dates per year for each cultivar and weighed to determine the total yield of each plant. A subsample of 100 berries was weighed on each date to calculate an average berry weight of each treatment, and 25 berries were sampled randomly to measure firmness. These latter berries were placed on their sides (calyx facing inward) on a turntable of a firmness tester (FirmTech 2; BioWorks Inc., Wamego, KS) and tested through the compression of the load. Reference size and deflection thresholds were set at
$18.87 \mathrm{~mm}$ and 0.51 to $1.47 \mathrm{~mm}$, respectively, and the mean of the replicate was recorded as grams of force per millimeter of deflection.

Approximately $150 \mathrm{~g}$ of ripe berries were also frozen from each treatment plot on each date and later analyzed to determine the percent soluble solids ( ${ }^{\circ}$ Brix $), \mathrm{pH}$, and titratable acidity on each harvest date. The frozen samples were thawed and pureed in a blender and measured to determine soluble solids using a refractometer (PAL-1; Atago USA. Inc., Bellevue, WA) and $\mathrm{pH}$ using a dual $\mathrm{pH} /$ ion meter (S80 SevenMulti; Mettler Toledo, Columbus, $\mathrm{OH})$. A 10-g sample of the puree was mixed in $100 \mathrm{~mL}$ of distilled water and titrated with $0.1 \mathrm{~mol} \cdot \mathrm{L}^{-1} \mathrm{NaOH}$ to an endpoint $\mathrm{pH}$ of 8.1 . Titratable acidity was calculated as a percentage of citric acid. Sugar-to-acid ratios were calculated by dividing the concentration of soluble solids in the berries by the percent of titratable acidity.

Fruit and vegetative buds were counted immediately after pruning each year (Feb. 2014 and Feb. 2015) to calculate fruit bud set. Fruit buds are much larger than vegetative buds in northern highbush blueberry and are readily visible when the plants are dormant in the winter (Strik et al., 1993). One lateral was randomly selected from each side of the two center plants in each plot for the measurement. Each lateral was $\approx 0.45 \mathrm{~m}$ in length and located in the middle of the bush.

Statistical analysis. Fruit bud set, yield, and fruit quality measurements were analyzed using Proc GLIMMIX in SAS 13.2 (SAS Institute, Cary, NC). Planned comparisons between the control and each water deficit treatment were performed at the 0.05 level using Fisher's protected least significant difference test.

\section{Results and Discussion}

Weather conditions at the site were cool and wet in the spring and warm and dry in the summer (Fig. 1). Daily air temperatures were similar during both years of the study and differed by an average of $<1{ }^{\circ} \mathrm{C}$ during each month of berry development. Precipitation was also similar between both years; from April through August, precipitation totaled $153 \mathrm{~mm}$ in 2013 and $160 \mathrm{~mm}$ in 2014 . Consequently, there was very little difference between these years in the timing of flowering and berry development within each cultivar (Fig. 1).

Most of the cultivars appeared to have a double-sigmoid pattern of fruit development (Fig. 1). In such cases, fruit growth could be divided into the three traditional stages during which fruit diameter increased exponentially during stages I and III and slowed during stage II (lag phase). Stages I and II coincided with the early green and late green stages of fruit development, respectively, whereas stage III corresponded to fruit coloring and accumulation of anthocyanins in the skins of berries (Zifkin et al., 2012). However, the lag phase was difficult to discern for 'Earliblue'; this has also been the case for early season cultivars of peach
[Prunus persica (L.) Batsch] (DeJong et al., 1987; Pavel and DeJong, 1993) and cherry $(P$. avium L.) (Lilleland and Newsome, 1934). It was also difficult to discern the lag phase of 'Duke' and the late-season cultivar, Elliott, during the second year. 'Aurora' had the longest lag phase among the cultivars, lasting $\approx 45 \mathrm{~d}$ each year.

Our intent was to expose each cultivar to soil water deficits during all three stages of fruit development (Fig. 1). However, there was too much rain both years to induce water deficits during the relatively short, late-green stage of 'Earliblue' and 'Duke'. Exposure to water deficits was also missed during the lategreen stage of 'Bluecrop'. As a result, water deficits were applied only twice per year to these three cultivars.

Plant and soil water status declined rapidly during water deficits, particularly when irrigation was stopped during warm, dry conditions in the later stages of fruit development (Figs. 2 and 3). During both years, volumetric soil water content was usually $<20 \%$ after 2 weeks without irrigation; when water was withheld during the final stage of fruit development, it was as low as $10 \%$ in the late-season cultivars. Consequently, the stem water potential declined most severely due to water deficits during the later stages of berry development. For example, when the plants were exposed to water deficits during the late green to fruit coloring or fruit coloring to blue stages of development in 2013, the stem water potential decreased no less than -1.3 $\mathrm{MPa}$ in 'Earliblue' and 'Duke' and $-1.4 \mathrm{MPa}$ in 'Bluecrop', but it was as low as -1.6 to $-1.7 \mathrm{MPa}$ in 'Elliott' and 'Aurora'. Bryla and Strik (2007) observed similar reductions in stem water potential with no rain or irrigation for $7 \mathrm{~d}$ in a mature planting of 'Duke', 'Bluecrop', and 'Elliott' blueberry that was otherwise irrigated once or twice per week using overhead sprinklers. $G_{\mathrm{S}}$ and photosynthesis decrease rapidly as stem water potential declines to less than -0.6 to $-0.8 \mathrm{MPa}$ in highbush blueberry (Bryla and Strik, 2006; Lobos et al., 2018) and, therefore, could reduce plant growth and fruit production (Bryla, 2011).

Soil water deficit had no effect on the yield of most cultivars during either year of the study; however, it reduced the yield of 'Aurora' each year when irrigation was withheld during the fruit coloring to blue stages of development (Table 1). A lower yield in this case was related to lower berry weights in the treatment. By the second year, 'Earliblue' and 'Elliott' had lower berry weights relative to the control when water deficits were applied during early and late stages of fruit development, whereas 'Aurora' had a slightly higher berry weight relative to the control when the water deficit was applied during the late-green to fruit coloring stage. Berry size often increases with less crop load for northern highbush blueberry (JorqueraFontena et al., 2014; Strik et al., 2003), which might have accounted for the heavier berry weights in this latter treatment. On average, 'Aurora' produced a total of 3100 and 2800 


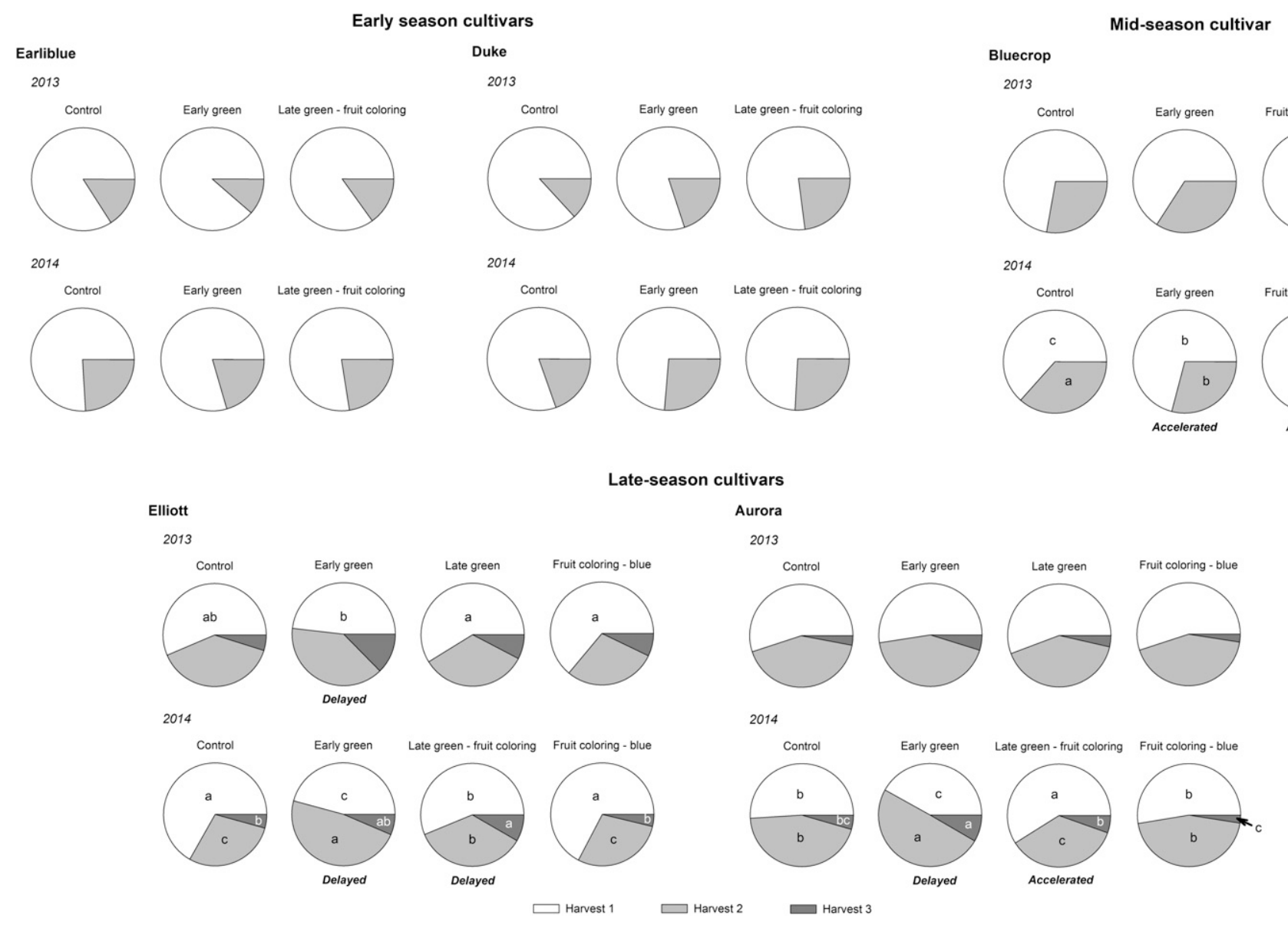

Fig. 4. Effects of soil water deficits on the proportion of the total yield picked at each harvest date of early-season ('Earliblue' and 'Duke'), midseason ('Bluecrop'), and late-season ('Elliott' and 'Aurora') cultivars of northern highbush blueberry during (A) 2013 and (B) 2014. Water deficits were applied by withholding irrigation for 2 weeks during the early green, late-green or late-green to fruit coloring, or fruit coloring to blue stages of fruit development (see Fig. 1 for details). Different letters within a harvest date (i.e., harvest 1,2 , or 3 ) of a given cultivar indicate means $(\mathrm{n}=5)$ were significantly different at $P \leq$ 0.05 according to Fisher's protected least significant difference test. Periods of water deficit that "accelerated" or "delayed" fruit ripening relative to the fully irrigated control or other treatments are identified below the pie charts.

berries/plant in the control and late water deficit treatments, respectively, during year 2 (data not shown).

Previously, we observed that fruit ripening of 'Elliott' blueberry was delayed when the plants were exposed to water deficits during early stages of fruit development and accelerated when irrigation was withheld for extended periods during later stages of development (Almutairi et al., 2017). We observed similar results in several cases during the present study (Fig. 4). For example, in 2014, water deficits delayed fruit ripening when irrigation was withheld during the early green stage (stage I) of 'Elliott' and 'Aurora' and accelerated ripening when irrigation was withheld during late green to fruit coloring (stage II-III) and fruit coloring to blue (stage III) stages of 'Aurora' and 'Bluecrop', respectively. However, in most cases, fruit ripening was unaffected by water deficits. Ripening was also accelerated when water deficit was applied during the early green stage (i.e., 'Bluecrop' in 2014) and delayed in another instance when it was applied during the late-green to fruit coloring stages (i.e., 'Elliott' in 2014). Accelerated ripening is a common result of water deficits in many fruit crops and attributed to a stress-induced increase in endogenous ethylene (Barry and Giovannoni, 2007). Delays, however, are often credited to reduced photosynthesis and lower availability of assimilates for the developing fruit (Hardie and Considine, 1976; Pomper and Breen, 1997).

Water deficits had numerous effects on the quality of the berries at harvest (Table 2). In many cases, water deficits reduced fruit firmness and/or increased the concentration of soluble solids in the berries. However, responses varied depending on the year, cultivar, and timing of the deficit. For example, water deficits at the early green stage (stage I) reduced the firmness of 'Duke' and 'Elliott' during both years of the study but had no effect on the firmness of the other cultivars. Water deficits at later stages of fruit development (stage II-III) also reduced firmness; however, in this case, it occurred during one or both years for each cultivar except 'Bluecrop'. Soluble solids were also variable and greater with an early water deficit for 'Duke' in 2013 and with late water deficits for 'Earliblue' and 'Aurora' in 2013 and 'Duke' and 'Aurora' in 2014. We and others previously demonstrated that severe water deficits consistently increased both firmness and soluble solids of northern and southern highbush blueberry (complex hybrids largely based on $V$. corymbosum and $V$. darrowii Camp.) due to their negative effect on fruit size (Almutairi et al., 2017; Bryla et al., 2009; Ehret et al., 2012, 2015; Lobos et al., 2018). Clearly, conflicting results of water deficits can arise from different stress intensities, strong genotype $\times$ environment interactions, and complex interactions among the numerous mechanisms involved in the final fruit quality (Ripoll et al., 2014).

In some cases, water deficit also reduced titratable acidity of the berries relative to full irrigation in the present study; however, in other cases, it had no effect or increased acidity (Table 2). Consequently, sugar-toacid ratios were variable among the treatments and often inconsistent from one year to the next. Sugar-to-acid ratios change considerably with the ripeness of the fruit, which undoubtedly differed among the cultivars and the date when we picked the berries (Strik, 2019). Such inconsistencies make it difficult to predict how mild or moderate water deficits affect the acidity and flavor of blueberries. 
Table 2. Effects of soil water deficits at different stages of fruit development on fruit quality of early-season ('Earliblue' and 'Duke'), midseason ('Bluecrop'), and late-season ('Elliott' and 'Aurora') cultivars of northern highbush blueberry.

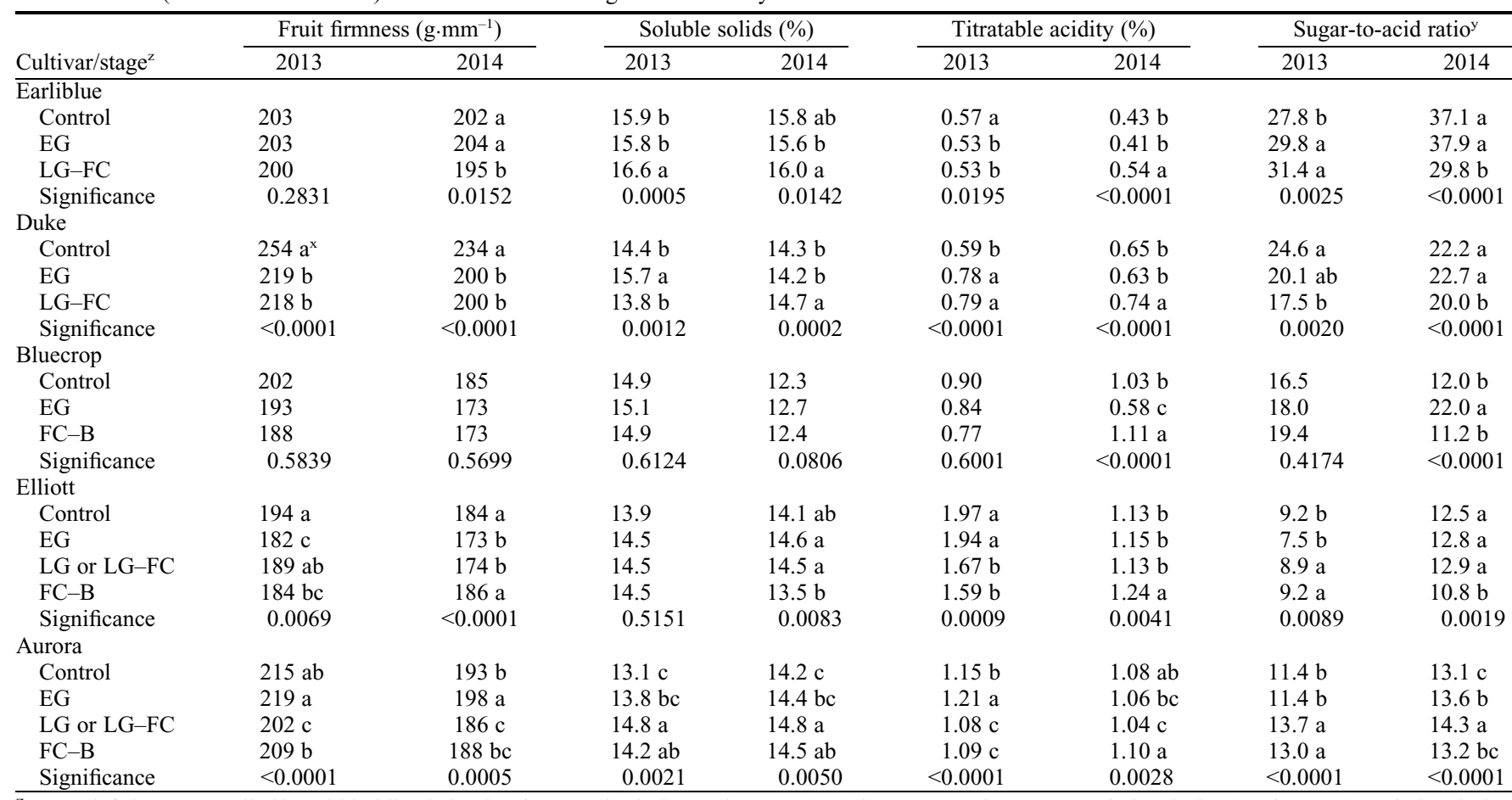

${ }^{\mathrm{z}}$ Water deficits were applied by withholding irrigation for 2 weeks during early green (EG), late-green or late-green to fruit coloring (LG/LG-FC), or fruit coloring to blue (FC-B) stages of fruit development (see Fig. 1 for details).

${ }^{\mathrm{y}}$ Calculated by dividing the concentration of soluble solids by titratable acidity

${ }^{\mathrm{x}}$ Means $(\mathrm{n}=5)$ were pooled across harvest dates and separated within each cultivar and year by Fisher's protected least significant difference test $(P \leq 0.05)$.

Table 3. Effects of soil water deficits at different stages of fruit development on the total number of buds per lateral and fruit bud set in early-season ('Earliblue' and 'Duke'), midseason ('Bluecrop'), and late-season ('Elliott' and 'Aurora') cultivars of northern highbush blueberry.

\begin{tabular}{|c|c|c|c|c|}
\hline \multirow[b]{2}{*}{ Cultivar/stage ${ }^{y}$} & \multicolumn{2}{|c|}{ Total buds (no./lateral) } & \multicolumn{2}{|c|}{ Fruit bud set (\%) } \\
\hline & 2014 & 2015 & 2014 & 2015 \\
\hline \multicolumn{5}{|l|}{ Earliblue } \\
\hline Control & 24.8 & 26.0 & 38.8 & 40.1 \\
\hline LG-FC & 25.3 & 25.0 & 38.8 & 44.3 \\
\hline Significance & 0.7366 & 0.5066 & 0.9915 & 0.2360 \\
\hline \multicolumn{5}{|l|}{ Duke } \\
\hline Control & 22.0 & 21.5 & 37.0 & $42.4 \mathrm{~b}$ \\
\hline Significance & 0.1620 & 0.4181 & 0.2762 & 0.0184 \\
\hline \multicolumn{5}{|l|}{ Bluecrop } \\
\hline Control & 35.9 & $34.8 \mathrm{~b}^{\mathrm{x}}$ & 42.9 & $41.6 \mathrm{~b}$ \\
\hline EG & 33.9 & $34.8 \mathrm{~b}$ & 37.4 & $40.5 \mathrm{~b}$ \\
\hline FC-B & 35.3 & $37.8 \mathrm{a}$ & 37.9 & $45.6 \mathrm{a}$ \\
\hline Significance & 0.4831 & 0.0292 & 0.0530 & 0.0174 \\
\hline \multicolumn{5}{|l|}{ Elliott } \\
\hline Significance & 0.1156 & 0.0011 & 0.3388 & $<0.0001$ \\
\hline \multicolumn{5}{|l|}{ Aurora } \\
\hline Control & 39.5 & $37.5 \mathrm{bc}$ & 38.8 & $39.8 \mathrm{~b}$ \\
\hline EG & 38.2 & $36.8 \mathrm{c}$ & 38.0 & $39.2 \mathrm{~b}$ \\
\hline LG or LG-FC & 40.0 & $41.4 \mathrm{ab}$ & 37.7 & $48.4 \mathrm{a}$ \\
\hline FC-B & 39.6 & $43.6 \mathrm{a}$ & 37.4 & $50.5 \mathrm{a}$ \\
\hline Significance & 0.7893 & 0.0011 & 0.8697 & $<0.0001$ \\
\hline
\end{tabular}

${ }^{\mathrm{z}}$ Fruit and vegetative buds were counted after pruning in Feb. 2014 and Feb. 2015.

${ }^{\mathrm{y}}$ Water deficits were applied by withholding irrigation for 2 weeks during the early green (EG), late-green or late-green to fruit coloring (LG/LG-FC), or fruit coloring to blue (FC-B) stages of fruit development (see Fig. 1 for details).

${ }^{\mathrm{x}}$ Means $(\mathrm{n}=5)$ were separated within each cultivar and year by Fisher's protected least significant difference test $(P \leq 0.05)$. 
Soil water deficits had no effect on the bud number or fruit bud set of any cultivar in Feb. 2014 (Table 3). However, 'Elliott' produced fewer buds the following year when water deficits were applied during the early green stage (stage I), and 'Bluecrop' and 'Aurora' produced more buds when water deficits were applied during fruit coloring to the blue stage (stage III). With the exception of 'Earliblue', most cultivars also had greater fruit bud set in Feb. 2015, when we applied water deficits during later stages of fruit development (stages II and III). Similar results occurred when 'Elliott' was exposed to no rain or irrigation for 4 to 6 weeks during early stages of fruit development (Almutairi et al., 2017). Moderate water deficits often favor the formation of flower buds of woody plants by inhibiting vegetative growth (Kozlowski and Pallardy, 1997). Visually, new shoot growth and new leaf growth were reduced by later water deficits during the second year of the present study (K. Almutairi, personal observations), which could have either decreased (fewer buds on the plants) or increased (a higher percentage of fruit bud set) the production of fruit the following year.

In summary, short 2-week periods of water deficit during various stages of berry development had little to no effect on yield but reduced the firmness of berries of most of the cultivars and berry weight of several cultivars. Predictably, water deficits applied during later stages of fruit development had the largest effects, particularly on mid- and late-season cultivars, which ripened primarily in July and August during the warmest and driest months of the year. Therefore, growers should focus their attention to irrigation of these cultivars and, if possible, apply water at least every 2 to $3 \mathrm{~d}$ during this time of year. However, irrigation was less critical during early stages of fruit development, suggesting this might be a good time to reduce irrigation if needed. Although we did not examine it during this study, water deficits occurring after harvest affect the initiation of flower buds of northern highbush blueberry and, therefore, could alter yield the following year (Mingeau et al., 2001). Because this may be the best time of year to reduce irrigation water use (Bryla, 2011), work is underway to determine the extent to which postharvest water deficits affect the fruit production of different cultivars of highbush blueberry.

\section{Literature Cited}

Abbott, J.D. and R.E. Gough. 1987. Seasonal development of highbush blueberry roots under sawdust mulch. J. Amer. Soc. Hort. Sci. 112:60-62.

Almutairi, K.F., D.R. Bryla, and B.C. Strik. 2017. Potential of deficit irrigation, irrigation cutoffs, and crop thinning to maintain yield and fruit quality with less water in northern highbush blueberry. HortScience 52:625-633, doi: 10.21273/HORTSCI11533-16.

Barry, C.S. and J.J. Giovannoni. 2007. Ethylene and fruit ripening. J. Plant Growth Regul. 26:143-159, doi: 10.1007/s00344-007-9002-y.

Bryla, D.R. 2011. Crop evapotranspiration and irrigation scheduling in blueberry, p. 167-
186. In: G. Gerosa (ed.). Evapotranspirationfrom measurements to agricultural and environmental applications. Intech, Rijeka, Croatia. doi: 10.5772/18311.

Bryla, D.R., J.L. Gartung, and B.C. Strik. 2011 Evaluation of irrigation methods for highbush blueberry-I. Growth and water requirements of young plants. HortScience 46:95-101, doi: 10.21273/HORTSCI.46.1.95.

Bryla, D.R. and B.C. Strik. 2006. Variation in plant and soil water relations among irrigated blueberry cultivars planted at two distinct in-row spacings. Acta Hort. 715:295300, doi: 10.17660/ActaHortic.2006.715.43.

Bryla, D.R. and B.C. Strik. 2007. Effects of cultivar and plant spacing on the seasonal water requirements of highbush blueberry. J. Amer. Soc. Hort. Sci. 132:270-277, doi: 10.21273/ JASHS.132.2.270

Bryla, D.R. and B.C. Strik. 2015. Nutrient requirements, leaf tissue standards, and new options for fertigation of northern highbush blueberry. HortTechnology 25:464-470, doi: 10.21273/ HORTTECH.25.4.464.

Bryla, D.R., B. Yorgey, and A.D. Shireman. 2009 Irrigation management effects on yield and fruit quality of highbush blueberry. Acta Hort. 810:649 656, doi: 10.17660/ActaHortic.2009.810.86.

Caspari, H.W., M.H. Behboudian, and D.J. Chalmers. 1994. Water use, growth, and fruit yield of 'Hosui' Asian pears under deficit irrigation. J. Amer. Soc. Hort. Sci. 119:383-388, doi 10.21273/JASHS.119.3.383.

Dalton, M.M., P.W. Mote, and A.K. Snover (eds.). 2013. Climate change in the Northwest: Implications for our landscapes, waters, and communities. Island Press, Washington, DC. doi: 10.5822/978-1-61091-512-0.

DeJong, T.M., J.F. Doyle, and K.R. Day. 1987. Seasonal patterns of reproductive and vegetative sink activity in early and late maturing peach (Prunus persica) cultivars. Physiol. Plant. 71:83-88, doi: 10.1111/j.1399-3054.1987.tb04621.x.

Eck, P. 1986. Blueberry. In: S.P. Monselise (ed.). 1986. CRC handbook of fruit set and development. CRC Press Inc., Boca Raton, FL. doi: 10.1201/9781351073042.

Egea, G., P.A. Nortes, R. Domingo, A. Baille, A Perez-Pastor, and M.M. Gonzalez-Real. 2013. Almond agronomic response to long-term deficit irrigation applied since orchard establishment. Irr. Sci. 31:445-454, doi: 10.1007/ s00271-012-0322-8.

Ehret, D.L., B. Frey, T. Forge, T. Helmer, and D.R. Bryla. 2012. Effects of drip irrigation configuration and rate on yield and fruit quality of young highbush blueberry plants. HortScience 47:414 421, doi: 10.21273/HORTSCI.47.3.414.

Ehret, D.L., B. Frey, T. Forge, T. Helmer, and D.R. Bryla. 2015. Age-related changes in response to drip irrigation in highbush blueberry. HortScience 50:486-490, doi: 10.21273/HORTSCI.50.3.486.

Jorquera-Fontena, E., M. Alberdi, and N. Franck. 2014. Pruning severity affects yield, fruit load and fruit and leaf traits of 'Brigitta' blueberry. J. Soil Sci. Plant Nutr. 14:855-868, doi: 10.4067/S0718-95162014005000068.

Godoy, C., G. Monterubbianesi, and J. Tognetti. 2008. Analysis of highbush blueberry (Vaccinium corymbosum L.) fruit growth with exponential mixed models. Scientia Hort. 115:368-376, doi: 10.1016/ j.scienta.2007.10.018.

Hardie, W.J. and J.A. Considine. 1976. Response of grapes of water-deficit stress in particular stages of development. Amer. J. Enol. Viticult. $27: 55-61$
Holzapfel, E.A. 2009. Selection and management of irrigation systems for blueberry. Acta Hort. 810:641648, doi: 10.17660/ActaHortic.2009.810.85.

Hsiao, T.C. 1990. Measurements of plant water status, p. 243-279. In: B.A. Steward and D.R. Nielsen (eds.). Irrigation of agriculture crops. Agron. Monogr. No. 30. ASA-CSSA-SSSA Publ., Madison, WI. doi: 10.1017/S0014479700021220.

Kozlowski, T.T. and S.G. Pallardy. 1997. Growth control in woody plants. Academic Press, San Diego, CA. doi: 10.1016/B978-0-12-4242104.X5000-1.

Li, S.H., J.G. Huguetu, P.G. Schoch, and P. Orlando. 1989. Response of peach tree growth and cropping to soil water deficit at various phenological stages of fruit development. J. Hort. Sci. 64:541552, doi: 10.1080/14620316.1989.11515989.

Lilleland, O. and L. Newsome. 1934. A growth study of the cherry fruit. Proc. Amer. Soc. Hort. 32:291-299.

Lobos, T.E., J.B. Retamales, S. Ortega-Ferías, E.J. Hanson, R. López-Olivari, and M.L. Mora. 2018. Regulated deficit irrigation effects on physiological parameters, yield, fruit quality and antioxidants of Vaccinium corymbosum plants cv. Brigitta. Irr. Sci. 36:49-60, doi: 10.1007/s00271-017-0564-6.

Lotter, J.D.V., D.J. Beukes, and H.W. Weber. 1985. Growth and quality of apples as affected by different irrigation treatments. J. Hort. Sci. 60:181-192, doi: 10.1080/14620316.1985.11515617.

McCutchan, H. and K.A. Shackel. 1992. Stemwater potential as a sensitive indicator of water stress in prune trees (Prunus domestica L. cv. French). J. Amer. Soc. Hort. Sci. 117:607-611, doi: 10.21273/JASHS.117.4.607.

Mills, T.M. and M.H. Behboudian. 1996. Water relations, growth, and the composition of 'Braeburn' apple fruit under deficit irrigation. J. Amer. Soc. Hort. Sci. 121:286-291, doi: 10.21273/JASHS.121.2.286.

Mingeau, M., C. Perrier, and T. Améglio. 2001. Evidence of drought sensitive periods from flowering to maturity on highbush blueberry. Scientia Hort. 89:23-40, doi: 10.1016/S03044238(00)00217-X.

Ojeda, H., A. Deloire, and A. Carbonneau. 2001 Influence of water deficits on grape berry growth. Vitis 40:141-145, doi: 10.5073/VITIS.2001.40.141145.

Pavel, E.W. and T.M. DeJong. 1993. Relative growth rate and its relationship to compositional changes of nonstructural carbohydrates in the mesocarp of developing peach fruits. J. Amer. Soc. Hort. Sci. 118:503-508, doi: 10.21273/JASHS.118.4.503.

Pomper, K. and P.J. Breen. 1997. Expansion and osmotic adjustment of strawberry fruit during water stress. J. Amer. Soc. Hort. Sci. 122:183189, doi: 10.21273/JASHS.122.2.183.

Ripoll, J., L. Urban, M. Staudt, F. Lopez-Lauri, L.P.R. Bidel, and N. Bertin. 2014. Water shortage and quality of fleshy fruits - making the most of the unavoidable. J. Expt. Bot. 65:40974117, doi: 10.1093/jxb/eru197.

Romero, P., J.M. Navarro, J. Perez-Perez, F Garcia-Sanchez, A. Gomez-Gomez, I. Porras, V. Martinez, and P. Botia. 2006. Deficit irrigation and rootstock: Their effects on water relations, vegetative development, yield, fruit quality and mineral nutrition of Clemenules mandarin. Tree Physiol. 26:1537-1548, doi: 10.1093/treephys/26.12.1537.

Shimura, I., M. Kobayashi, and S. Ishikawa. 1986. Characteristics of fruit growth and development in highbush and rabbiteye blueberries (Vaccinium corymbosum L. and $V$. ashei 
Reade) and the differences among their cultivars. J. Jpn. Soc. Hort. Sci. 55:46-50.

Strik, B.C. 2019. Frequency of harvest affects berry weight, firmness, titratable acidity, and percent soluble solids of highbush blueberry cultivars in Oregon. J. Amer. Pomol. Soc. 73:254-268.

Strik, B., C. Brun, M. Ahmedullah, A. Antonelli, L. Askam, D. Barney, P. Bristow, G. Fisher, J. Hart, D. Havens, R. Ingham, D. Kaufman, R. Penhalgon, J. Pscheidt, B. Scheer, C. Shanks, and R. William. 1993. Highbush blueberry production. Ore. State Univ. Ext. Serv. Pub. PNW 215.
Strik, B., G. Buller, and E. Hellman. 2003. Pruning severity affects yield, berry weight, and hand harvest efficiency of highbush blueberry. HortScience 38:196-199, doi: 10.21273/HORTSCI.38.2.196.

Strik, B.C., C.E. Finn, and P.P. Moore. 2014. Blueberry cultivars for the Pacific Northwest. Oregon State Univ. Ext. Serv. PNW656. 15 Apr. 2020. <https://catalog.extension.oregonstate.edu/sites/catalog/files/project/pdf/pnw656.pdfs.

Vargas, O.L., D.R. Bryla, J.E. Weiland, B.C. Strik, and L. Sun. 2015. Irrigation and fertigation with drip and alternative micro irrigation systems in northern highbush blueberry. HortScience 50:897-903, doi: 10.21273/HORTSCI.50.6.897.
Wilk, P., G. Carruthers, C. Mansfield, and V. Hood. 2009. Irrigation and moisture monitoring in blueberries. NSW Department of Primary Industries (NSW DPI). 15 Apr. 2020. <https:// www.dpi.nsw.gov.au/_data/assets/pdf_file/0016/ 303325/Irrigation-and-moisture-monitoring-inblueberries.pdf>.

Zifkin, M., A. Jin, J.A. Ozga, L.I. Zaharia, J.P Schernthaner, A. Gesell, S.R. Abrams, J.A. Kennedy, and C.P. Constabel. 2012. Gene expression and metabolite profiling of developing highbush blueberry fruit indicates transcriptional regulation of flavonoid metabolism and activation of abscisic acid metabolism. Plant Physiol. 158:200-224, doi: 10.1104/pp.111.180950. 